\title{
PGC-1 $\beta$ cooperating with FOXA2 inhibits proliferation and migration of breast cancer cells
}

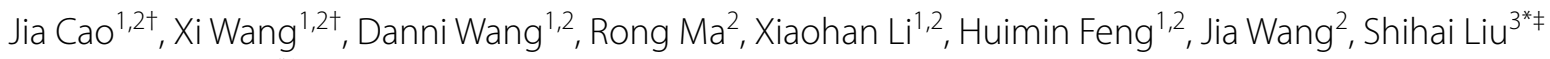
and Libin Wang ${ }^{1,2^{*} \neq}$

\begin{abstract}
Background: Breast cancer is one of the most common malignancy among females from the worldwide cancer incidence statistics. Peroxisome gamma coactivator-1 $\beta$ (PGC-1 $\beta$ ) has long been identified to be involved in this type of tumorigenesis. However, the mechanisms of PGC-1 1 in human breast cancer have not been fully understood and the function requires to be further elucidated.

Methods: mRNA and protein expression of PGC-1 $\beta$ and FOXA2 in breast cancer tissues and cell lines were determined by qRT-PCR and Western Blotting, respectively. To further visualize the expression and localization of PGC-1 $\beta$ and FOXA2, immunochemistry and immunofluorescence staining methods were employed. The effect of PGC-1 $\beta$ and FOXA2 on cell proliferation and migration were evaluated by CCK8, clone formation, transwell and wound-healing assays, which has been done either with stable PGC-1 $\beta$ knockdown or FOXA2 overexpression in vitro. Xenografts model of nude mice were used to evaluate tumor growth in vivo. In addition, proteins expression of the PI3K-AKTmTOR signaling pathway involved in the regulation of breast cancer were detected by Western Blotting.
\end{abstract}

Results: Our results showed that PGC-1 $\beta$ was upregulated and FOXA2 was downregulated in breast cancer tissues and cell lines. These two proteins can be interacted with each other to form the complex. Also, we found the combination of PGC-1 $\beta$ interference with FOXA2 overexpression significantly inhibited cell proliferation and migration in vitro as well as tumor growth in vivo. We further identified that PGC-1 $\beta$ and FOXA2 strongly correlated with the PI3K-AKT-mTOR signaling pathway, and they exerted their biological functions by activating this pathway.

Conclusions: We demonstrated that downregulation of PGC-1 $\beta$ combined with overexpression of FOXA2 obviously inhibited the function of breast cancer cells through regulating the PI3K-AKT-mTOR pathway.

Keywords: PGC-1ß, FOXA2, Breast cancer, Proliferation, Migration

\section{Background}

Breast cancer is one of the most common malignancy among women all over the world [1]. The latest survey shows more than 2000 million newly diagnosed patients

\footnotetext{
*Correspondence: shliumed@126.com; wanglibin007@126.com

†Jia Cao and Xi Wang contributed equally to this work

FShihai Liu and Libin Wang contributed equally to this work

${ }^{2}$ Beijing National Biochip Research Center Sub-Center in Ningxia, The

General Hospital of Ningxia Medical University, Yinchuan 750004, China

${ }^{3}$ Medical Animal Lab, The Affiliated Hospital of Qingdao University,

Qingdao 266003, China

Full list of author information is available at the end of the article
}

of breast cancer have occurred in the worldwide. And the incidence and mortality of breast cancer have increased by nearly $18 \%$ since 2008 [2]. Breast cancer is a diverse hormone-dependent carcinoma, with both genetic and epigenetic changes leading to initiation, progression and metastasis [3]. Despite significant advances have been made in the biological development of breast cancer, the occurrence of metastasis still leads to poor prognosis and low survival. Therefore, discovery of the new biomarkers and development of the targeted therapeutics strategies are urgently needed for diagnosis and treatment of breast cancer.

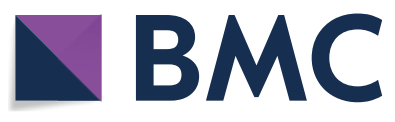

(c) The Author(s) 2019. This article is distributed under the terms of the Creative Commons Attribution 4.0 International License (http://creativecommons.org/licenses/by/4.0/), which permits unrestricted use, distribution, and reproduction in any medium, provided you give appropriate credit to the original author(s) and the source, provide a link to the Creative Commons license, and indicate if changes were made. The Creative Commons Public Domain Dedication waiver (http://creativecommons.org/ publicdomain/zero/1.0/) applies to the data made available in this article, unless otherwise stated. 
The peroxisome proliferator-activated receptor (PPAR) gamma coactivator-1 (PGC-1) family of transcriptional coactivators, mainly including PGC- $1 \alpha$ and PGC- $1 \beta$, have emerged as being major regulators of mitochondrial biogenesis and cellular metabolism to regulate the cellular bioenergetics $[4,5]$. The members of PGC- 1 family are multifunctional transcriptional co-regulators that take on "molecular switches" in many physiological and pathological processes [6]. They are highly expressed in oxidative capacity and energy demanding tissues, such as heart, brain, skeletal muscle and brown adipose tissue [7-10] and considered to be essential for many of exercise response in skeletal muscle [11]. Specifically, PGC- $1 \alpha$ and PGC-1 $\beta$ can interact with each other, or interact with multiple transcription factors, such as forkhead/winged helix protein family member FOXO1, and nuclear respiratory factor-1/2 (NRF1/2) in tissue specific manner $[5,12]$ to modulate in mitochondrial biogenesis, fatty acid $\beta$-oxidation, adipogenesis, adaptive thermogenesis and tricarboxylic acid cycle [13, 14].

The PGC- $1 \beta$ protein, encoded by the PPARGC1 $\beta$, is located on chromosome $5 q 33.1$. PGC-1 $\beta$ has involved in many biological processes. For example, it is a biological candidate gene in relation to obesity and obesity related type 2 diabetes [15]; hepatic PGC-1 $\beta$ as a transcriptional gatekeeper of mitochondrial function, contributes to hepatocellular carcinoma progression [16]. It has been reported that PGC-1 $\beta$ was closely related to the tumor biological properties and cancer cells proliferation via metabolic and redox pathways [17]. Our previous research proved that PGC-1 $\beta$ was significantly overexpressed in breast cancer and inhibited the apoptosis of breast cancer cells via mTOR signaling pathway [18]. Therefore, we postulated the PGC- $1 \beta$ may play an important role in the development and progression of breast cancer.

The forkhead box protein A2 (FOXA2), a pioneer transcription factor, is one of the members of forkhead/ winged-helix family that comprises the transcription factors FOXA1, FOXA2 and FOXA3 in mammals [19-21]. Previous studies have shown that FOXA2 is a critical regulator of embryonic development, and plays a key role in the pathogenesis and occurrence of various cancers, such as prostate cancer [22, 23], liver cancer [24, 25], pancreatic cancer [26], and breast cancer [27, 28]. The expression of FOXA2 can prevent the development and progression of the above cancers [29]. In addition, FOXA2 can regulate transcription factor expression, and involve in a variety of biological processes, including cell growth, proliferation, migration, differentiation and autophagy in multiple human tumors [30-33]. Given that FOXA2 exerts essential roles in these processes, the loss or gain of FOXA2 function can modify the tumor biological behavior and participate in tumorigenesis.
PGC-1 $\beta$ and FOXA2 have some similar functions, such as regulating the lipid metabolism and modulating the function of other transcription factors. In the present study, we aimed to elucidate the role of PGC-1 $\beta$ and FOXA2 in breast cancer progression. We found that PGC- $1 \beta$ is upregulated and FOXA2 is downregulated in breast cancer tissues and cell lines. PGC-1 $\beta$ cooperating with FOXA2 can regulate the tumor cells proliferation, migration and apoptosis in vitro and vivo. Meanwhile, we identified that PGC- $1 \beta$ interacts with FOXA2, and it synergizes with FOXA2 to inhibit the biological functions of breast cancer cells through regulating the PI3K-AKTmTOR signaling pathway. Together, our study highlights the PGC- $1 \beta$ and FOXA2 may be potential targets for the development of breast cancer.

\section{Materials and methods}

\section{Cell line and cell culture}

Human breast cancer cell lines (MCF-7 and MDAMB-231) and normal human breast cell line (MCF-10A) were purchased from the Cell bank of the Chinese Academy of Sciences/American Type Culture Collection (ATCC, VA, USA). Human breast cancer cell line (BT549) was donated by Dr. Liu from the Affiliated Hospital of Qingdao University. The above cells were maintained and cultured in DMEM HIGH GLUCOSE medium (HyClone, Logan, USA) supplemented with $10 \%$ fetal bovine serum (Gibco, Australia) and 1\% penicillin-streptomycin solution in the incubator at $37{ }^{\circ} \mathrm{C}$ under $5 \% \mathrm{CO}_{2}$.

\section{Clinical cancer tissue samples}

A total of 30 paired breast cancer tissues and adjacent non-tumor tissues samples were collected and obtained undergoing breast carcinectomy from the General Hospital of Ningxia Medical University. The fresh samples were frozen and stored in liquid nitrogen until further use. All the tissue samples were signed by patients with informed consent.

\section{Western Blotting}

The cells were harvested and lysed using RIPA lysis buffer containing configure RIPA, PIC, and PMSF at a ratio of 100:2:1 (Beyotime Biotechnology, Shanghai, China). The total protein was extracted and the protein concentration was detected by BCA protein reagent kit (Thermofisher Scientific, Inc). The samples were electrophoresed on $10 \%$ SDS-PAGE and transferred to PVDF membranes. The membranes were blocked with $5 \%$ defatted milk in TBST for $1 \mathrm{~h}$ at room temperature and then incubated with specific primary antibodies overnight at $4{ }^{\circ} \mathrm{C}$ (Table 1). Subsequently, the HRP-conjugated secondary antibodies were incubated at room temperature for $1.5 \mathrm{~h}$. The protein bands were detected and scanned 
by Biolmaging Systems (BIO-RAD, CA, USA). AntiGAPDH antibody was used as an internal control to normalize protein levels.

Real time quantitative reverse transcription-PCR (qRT-PCR) Total RNA was extracted from tissues and cells using TRIzol reagent (Invitrogen, CA, USA) as per manufacturer's instructions. cDNA synthesis was performed by using a reverse transcription kit (TaKaRa, ShangHai, China) according to the manufacturer's protocols. The PCR amplification was performed with specific primers and carried out using the SYBR-Green PCR system (Takara Bio, Inc). GAPDH or $\beta$-actin served as internal control. Calculation of the relative expression of each gene was quantified by the $2^{-\Delta \Delta C t}$ method.

\section{Plasmids and cell transient transfection}

The plasmids, including shRNA for PGC-1 $\beta$ (sh-PGC-1 $\beta$ ), shRNA-NC (NC), pcDNA3.1-PGC-1 $\beta$ (PGC-1 $\beta$ ), pcDNA3.1-FOXA2 (FOXA2), shRNA for FOXA2 (sh-FOXA2) were designed and synthesized by Shanghai Genechem Co.Ltd (Shanghai, China). MCF-7 and MDA-MB-231 cells were plated in six-well plates, and the cells were transfected with $2.5 \mu \mathrm{g}$ plasmid using Lipofectamine 3000 (Invitrogen, CA, USA) when the cell density reaches $70-80 \%$ confluence according to the manufacturer's protocol. Cell transfection efficiency was observed under fluorescence microscope and examined using qRT-PCR and western blot assays.

\section{Cell proliferation and colony formation assays}

The cell proliferation ability was assessed with CCK-8 assay and clone formation assay. For the CCK- 8 assay, MCF-7 or MDA-MB-231 cells were seeded in 96-well

\begin{tabular}{llll}
$\begin{array}{l}\text { Table } \mathbf{1} \text { The } \\
\text { analysis }\end{array}$ & antibodies & used in the western & blotting \\
\hline Protein & Producer & Catalog number & Dilution \\
\hline PGC-1 $\beta$ & NOVUS & NB110-58858G & $1: 500$ \\
FOXA2 & Abcam & $a b 108422$ & $1: 1000$ \\
GAPDH & Abcam & $a b 128915$ & $1: 5000$ \\
P-AKT & Abcam & $a b 38449$ & $1: 500$ \\
AKT & CST & $\# 9272$ & $1: 1000$ \\
PI3K & CST & $\# 4257$ & $1: 500$ \\
mTOR & CST & $\# 2983$ & $1: 500$ \\
Rictor & CST & $\# 2114$ & $1: 1000$ \\
Raptor & CST & $\# 2280$ & $1: 1000$ \\
PDK1 & CST & $\# 3062$ & $1: 1000$ \\
\hline
\end{tabular}

CST cell signaling technology plates and were cultured for $24,48,72 \mathrm{~h}$, respectively. The cells were then treated with CCK- 8 reagent (KeyGEN BioTECH, Jiangsu, China) and further cultured for $2 \mathrm{~h}$ according to the manufacturer's instructions. The optical density was measured using the spectrophotometer (Glomax Multi Detection Systerm, Promega, USA) at $450 \mathrm{~nm}$. Each group of experiments included five replicates and repeated three times.

For the colony formation assay, $8 \times 10^{3}$ cells were added into 6-well plate and suspended in DMEM medium. The cells were exchanged every 3 days until the 12 days. Then, these dishes were fixed with $100 \%$ methanol for $15 \mathrm{~min}$ and stained with crystal violet for $10 \mathrm{~min}$. The number of colonies were observed and calculated from representative areas. All experiments were performed in triplicate.

\section{Migration assays}

The migration ability of the tumor cells were examined by transwell and wound healing assays. The cells were seeded in twelve-well plate and transfected with interfering or overexpressing plasmids for $48 \mathrm{~h}$. The cell monolayer was wounded by scraping with $200 \mu \mathrm{l}$ pipet tip and the exfoliated cells were washed with PBS. Subsequently, the speed of wound closure was observed and photographed under a microscope. Cell mobility was assessed by measuring three randomly perpendicular wound width. For the transwell assay, Corning Incorporated transwell Chambers (Corning, $8 \mu \mathrm{m}$, NY, USA) were used to detect the cells of migration capacity. The chambers were placed into a 24-well plate containing culture medium supplemented with $20 \%$ FBS as a chemo-attractant. After transfection with 48 h, MCF-7 and MDA-MB-231 cells were collected and suspended in serum-free medium and loaded onto the upper chamber, incubated and allowed to migrate at for $24 \mathrm{~h}$ and $48 \mathrm{~h}$, respectively. The cells were fixed with $4 \%$ paraformaldehyde for $15 \mathrm{~min}$ and stained with crystal violet for $10 \mathrm{~min}$. The non-invading cells were removed using swab, whereas total numbers of cells were imaged and counted from representative areas under a microscope (Olympus, Tokyo, Japan).

\section{Flow cytometry}

MCF-7 and MDA-MB-231 cells were planted in six-well plate and treated with transfection reagent for $48 \mathrm{~h}$, and the cells were digested with trypsin without EDTA and counted $1 \times 10^{6}$ cells for analysis of each sample. After being washed twice with cold PBS, the cells were collected and prepared to form a single cell suspension in a binding buffer, and stained with AnnexinV-APC for $10 \mathrm{~min}$ and propidium iodide (PI) for $10 \mathrm{~min}$ according to instructions of the AnnexinV-APC/PI apoptosis 
detection kit (BestBio, Shanghai, China). Samples were examined using BD flow cytometer and the data were analyzed with FlowJo software (TreeStar Corporation, Ashland, OR, USA).

\section{Immunofluorescence staining}

Cells were grown in 24-well chamber slides (NEST, USA) for $48 \mathrm{~h}$, and washed with cold PBS and fixed in $4 \%$ paraformaldehyde for $15 \mathrm{~min}$. Subsequently, the coverslips were permeabilized with $0.3 \%$ Triton X-100 for 6 min and blocked with $5 \%$ normal goat serum for $30 \mathrm{~min}$ at room temperature. Then, the cells were incubated with antiPGC-1 $\beta$ (ab176328, Abcam) and anti-FOXA2 (ab117542, Abcam) overnight at $4{ }^{\circ} \mathrm{C}$, and followed by incubation with fluorescent secondary antibody for $1 \mathrm{~h}$ at room temperature. The nucleus was visualized with DAPI solution (dilution: 1:1000, Sigma, USA) for 6 min in the dark. Confocal laser scanning microscope was utilized for image analysis.

\section{Immunohistochemistry}

The paraffin-embedded tissues were deparaffinized using xylene and rehydrated through graded concentrations of alcohol solution. The slides were incubated with $0.3 \%$ hydrogen peroxide for $30 \mathrm{~min}$ to inactivate endogenous peroxidase prior to the infiltration of the citrate buffer with the tissue parts to repair the antigen in a microwave. The slides were rinsed with PBS for $15 \mathrm{~min}$, blocked with $5 \%$ goat serum for $1 \mathrm{~h}$ at room temperature and incubated with the primary antibodies at $4{ }^{\circ} \mathrm{C}$ overnight. Subsequently, the slides were incubated with biotinylated secondary antibody at room temperature for $1 \mathrm{~h}$. The sections were visualized with 3, 3'-diaminobenzidine (DAB) chromogenic fluid and counterstained with hematoxylin (CWBIO, Beijing, China).

\section{Co-immunoprecipitation assay}

293T and MCF7 cells were seeded in $10 \mathrm{~cm}$ dish, and were co-transfected with PGC-1 $\beta$ and FOXA2 overexpression plasmids by Lipofectamine 3000 . The cells were lysed using RIPA lysis buffer containing protease inhibitor cocktails (Thermo, USA). The cell lysates were used in immunoprecipitation after centrifuged at $12,000 \mathrm{rpm}$ for $20 \mathrm{~min}$. The proteins extracted from the cells were incubated the primary antibody or normal mouse/rabbit IgG at $4{ }^{\circ} \mathrm{C}$ for $4-6 \mathrm{~h}$ and then incubated with $30 \mu \mathrm{l}$ Protein A/G Plus-Agarose beads (GE Healthcare Bio-Sciences, Sweden) for overnight. The immune complexes were precipitated by centrifuged for $5 \mathrm{~min}$, and the precipitates were washed three times with corresponding washing buffer. The precipitates were resuspended in $5 \times$ SDSPAGE sample loading buffer to boiled $\left(100^{\circ} \mathrm{C}\right)$ for $10 \mathrm{~min}$ for western blot assay.

\section{Tumor xenograft model}

MDA-MB-231 cells were infected with lentivirus vector and subcutaneously implanted into 4-6-week-old female BalB/C nude mice, which purchased from the Beijing Vital River Laboratory Animal Technology Co. Ltd (Beijing, China). The tumor nodules were assessed with electronic calipers by recording tumor length and width for 15 days. Subsequently, the mice were euthanized and tumor mass were collected, weighed and photographed. All animal experiments were performed in accordance with principles and guidelines approved by the Ethics Committee of Animal Research.

\section{Statistical analysis}

Statistical testing was performed with the SPSS 17.0, GraphPad Prism version 6.0 and Microsoft Office Excel 2013 software. All assays were conducted three times and results were presented as mean \pm SD. Statistical differences among groups were determined by two-tailed Student $t$ test or one-way analysis of variance (one-way ANOVA). Results were considered significant when $\mathrm{P}$ values $<0.05$.

\section{Results}

\section{Expression levels of PGC-1 $\beta$ and FOXA2 in breast cancer tissues and cells}

To detect expression of PGC-1 $\beta$ and FOXA2 in breast cancer, qRT-PCR was performed on 30 pairs of breast cancer tissues and adjacent normal tissues. Elevated levels of PGC-1 $\beta$ and low levels of FOXA2 were observed in breast cancer tissues (Fig. 1a). Moreover, we examined the expression of both genes in human breast cancer cell lines (MCF-7, MDA-MB-231 and BT-549) and normal breast cell line (MCF-10A). Consistent with the findings in the clinical breast cancer specimens, the PGC- $1 \beta$ mRNA and protein expression levels were significantly upregulated in the breast cancer cell lines. Whereas, the expression of FOXA2 was negatively correlated with PGC-1 $\beta$ (Fig. 1b, c). Results from human breast cancer tissues indicated that abnormal expression of PGC- $1 \beta$ was closely related to the clinicopathological characteristics of patients, such as Lymph node metastasis $(\mathrm{P}=0.026)$ and Progesterone receptor $(\mathrm{P}=0.026)$ (Table 2$)$. Immunohistochemical assay showed strong staining of PGC-1 $\beta$ and weak staining of FOXA2 were observed in breast tumor tissues, which was consistent with the above results (Fig. 1d). Moreover, we detected the localization of PGC-1 $\beta$ and FOXA2 through immunofluorescence assay. It was found that PGC-1 $\beta$ localized mainly in the cytoplasm, and FOXA2 localized mostly in the nucleus (Fig. 1e). Collectively, these data clearly demonstrated that abnormal expression of PGC-1 $\beta$ and FOXA2 were 


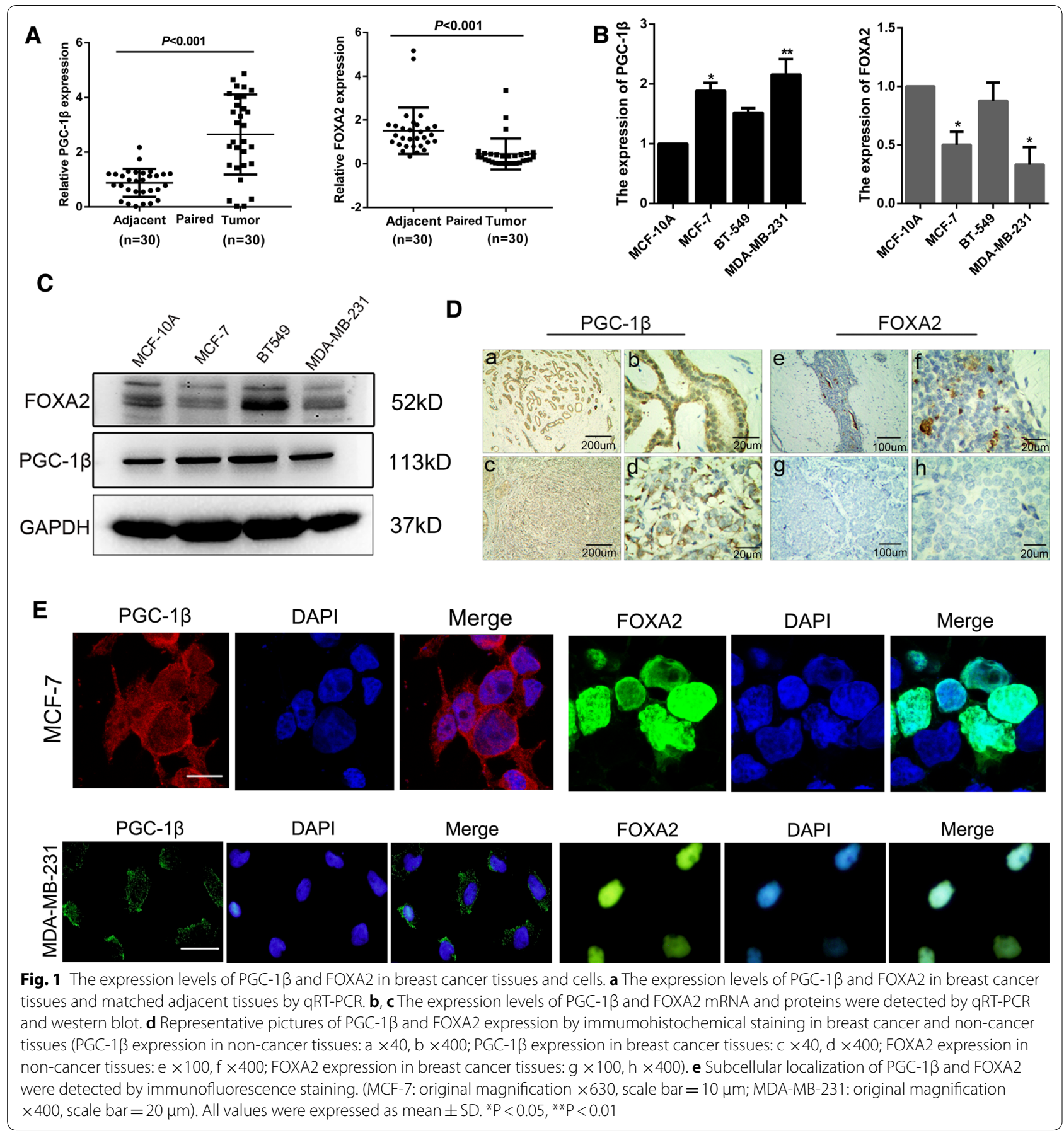

frequent event in breast cancer, and they might play vital roles in the development and progression of breast cancer.

\section{PGC-1 $\beta$ cooperating with transcription factor FOXA2}

To confirm the interaction of PGC-1 $\beta$ and FOXA2, we detected the binding of two proteins in MCF-7 cell by Co-immunoprecipitation (Co-IP) assay. The
FLAG-tagged PGC-1 $\beta$ and HA-tagged FOXA2 were co-expressed into MCF-7 cells. As shown in Fig. 2a, anti-FLAG antibody was co-precipitated with HAFOXA2. However, HA-FOXA2 did not pull down FLAG-PGC-1 $\beta$. Co-IP assay indicated that endogenous PGC- $1 \beta$ protein might target to FOXA2 in breast cancer. The subcellular colocalization of PGC- $1 \beta$ and FOXA2 were examined to further determine whether 
Table 2 The relevance of PGC-1 $\beta$ expression to clinicopathological features of breast cancer patients

\begin{tabular}{|c|c|c|c|c|}
\hline \multirow[t]{2}{*}{ Characteristics } & \multirow[t]{2}{*}{ N (\%) } & \multicolumn{2}{|c|}{ PGC-1 $\beta$ expression } & \multirow[t]{2}{*}{$P$ value } \\
\hline & & Positive (\%) & Negative (\%) & \\
\hline \multicolumn{4}{|l|}{ Age (years) } & 0.563 \\
\hline$<50$ & $11(36.7)$ & 7 (63.6) & $4(36.4)$ & \\
\hline$\geq 50$ & $19(63.3)$ & $14(73.7)$ & $5(26.3)$ & \\
\hline \multicolumn{4}{|l|}{ TNM stage } & 0.207 \\
\hline$|-| \mid$ & $22(73.3)$ & $14(63.6)$ & $8(36.4)$ & \\
\hline III & $8(26.7)$ & $7(87.5)$ & $1(12.5)$ & \\
\hline \multicolumn{4}{|l|}{ Tumor size (cm) } & 0.469 \\
\hline$\leq 2$ & $13(43.3)$ & $10(76.9)$ & $3(23.1)$ & \\
\hline$>2$ & $17(56.7)$ & $11(64.7)$ & $6(35.3)$ & \\
\hline \multicolumn{4}{|c|}{ Lymph node metastasis } & $0.026^{*}$ \\
\hline Negative & $11(36.7)$ & $5(45.5)$ & $6(54.5)$ & \\
\hline Positive & $19(63.3)$ & $16(84.2)$ & $3(15.8)$ & \\
\hline \multicolumn{4}{|c|}{ Estrogen receptor } & 0.207 \\
\hline Negative & $8(26.7)$ & $7(87.5)$ & $1(12.5)$ & \\
\hline Positive & $22(73.3)$ & $14(63.6)$ & $8(36.4)$ & \\
\hline \multicolumn{4}{|c|}{ Progesterone receptor } & $0.026^{*}$ \\
\hline Negative & $11(36.7)$ & $5(45.5)$ & $6(54.5)$ & \\
\hline Positive & $19(63.3)$ & $16(84.2)$ & $3(15.8)$ & \\
\hline \multicolumn{4}{|l|}{ HER2 receptor } & 0.232 \\
\hline Negative & $15(50.0)$ & $9(60.0)$ & $6(40.0)$ & \\
\hline Positive & $15(50.0)$ & $12(80.0)$ & $3(20.0)$ & \\
\hline
\end{tabular}

$P$ value from Chi square test $\left({ }^{*} \mathrm{P}<0.05\right)$

PGC-1 $\beta$ can combine with FOXA2 physically through immunofluorescence (IF) staining. The overexpression plasmids of PGC-1 $\beta$ and FOXA2 were transfected into HEK293T and MCF-7 cell lines. The cells were fixed and incubated with anti-PGC-1 $\beta$ and anti-FOXA2 antibodies. PGC-1 $\beta$ was found to be mainly expressed in the cytoplasm in the cells transfected with PGC-1 $\beta$ plasmid alone, and FOXA2 was expressed in the nucleus in the cells transfected with FOXA2 plasmid only. Interestingly, PGC- $1 \beta$ and FOXA2 were co-localized in the nucleus when the cells were co-transfected with PGC-1 $\beta$ and FOXA2 overexpression plasmids (Fig. $2 \mathrm{~b}, \mathrm{c}$ ). These findings suggested that PGC-1 $\beta$ and FOXA2 can physically interact with each other and form complex.

\section{Transient PGC-1 $\beta$-suppressed and FOXA2-overexpressed cells were constructed}

The specific shRNA against PGC-1 $\beta$ (sh-PGC-1 $\beta$ ) and overexpression against FOXA2 (FOXA2) were transfected with MCF-7 and MDA-MB-231 cells. The results indicated that compared with the corresponding control group $(\mathrm{NC})$, transfection of sh-PGC-1 $\beta$ reduced the expression of endogenous PGC-1 $\beta$ (Fig. 3a) and transfection of FOXA2 overexpression significantly increased FOXA2 expression (Fig. 3d) by qRT-PCR assay. At the same time, the MCF-7 and MDA-MB-231 cells were also transfected with the overexpression plasmid of PGC-1 $\beta$ and the interference plasmid of FOXA2. The results showed that there were no significant difference between the two groups $(P>0.05$, Fig. $3 \mathrm{~b}, \mathrm{c})$. Western Blotting results showed that transfected with PGC- $1 \beta$ interference and FOXA2 overexpression vector, the proteins expression of PGC-1 $\beta$ and FOXA2 were decreased and increased, respectively (Fig. 3e, f). Therefore, the PGC-1 $\beta$ interference and FOXA2 overexpression vectors were used for the subsequent experimental studies.

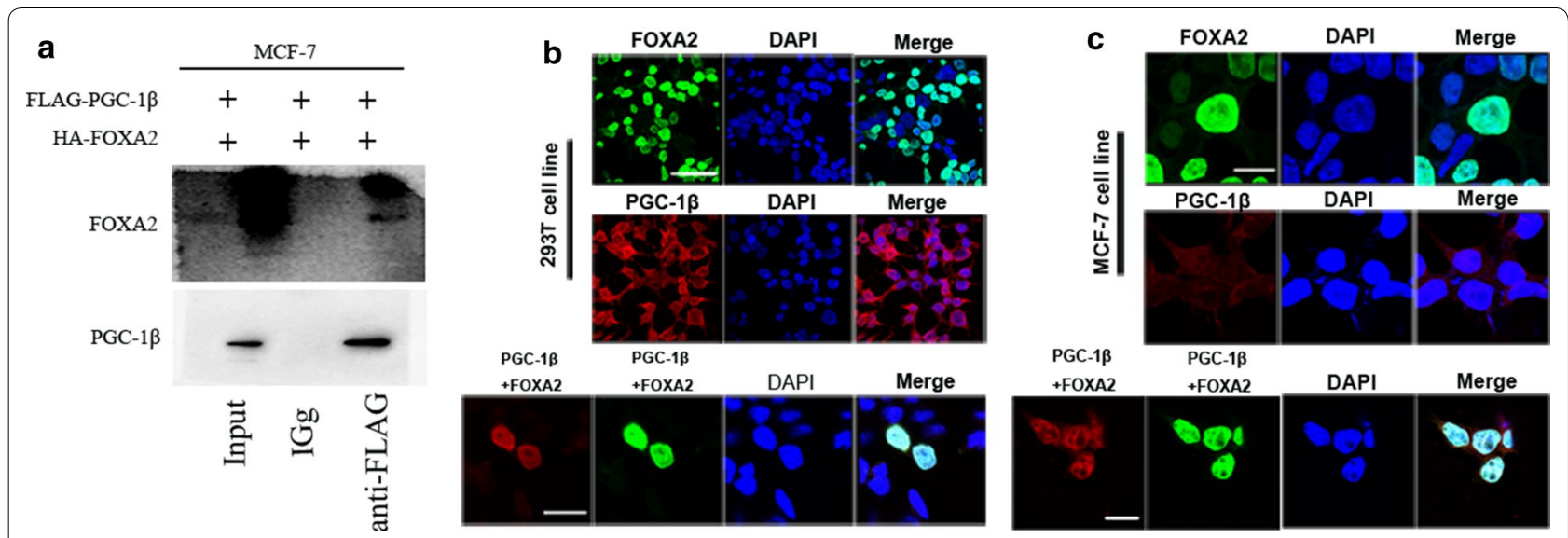

Fig. 2 PGC-1 $\beta$ cooperating to transcription factor FOXA2. a Combination of PGC-1 $\beta$ and FOXA2 proteins. MCF7 cells were transfected with FLAG-PGC-1 $\beta$ and HA-FOXA2. Input group was used as a positive control, and normal lgG group was used as a negative control. b, c Colocalization of PGC-1 $\beta$ and FOXA2 in 293T and MCF-7 cell lines by immunofluorescence staining (magnification $\times 400$; scale bar $=20 \mu \mathrm{m}$ ) 


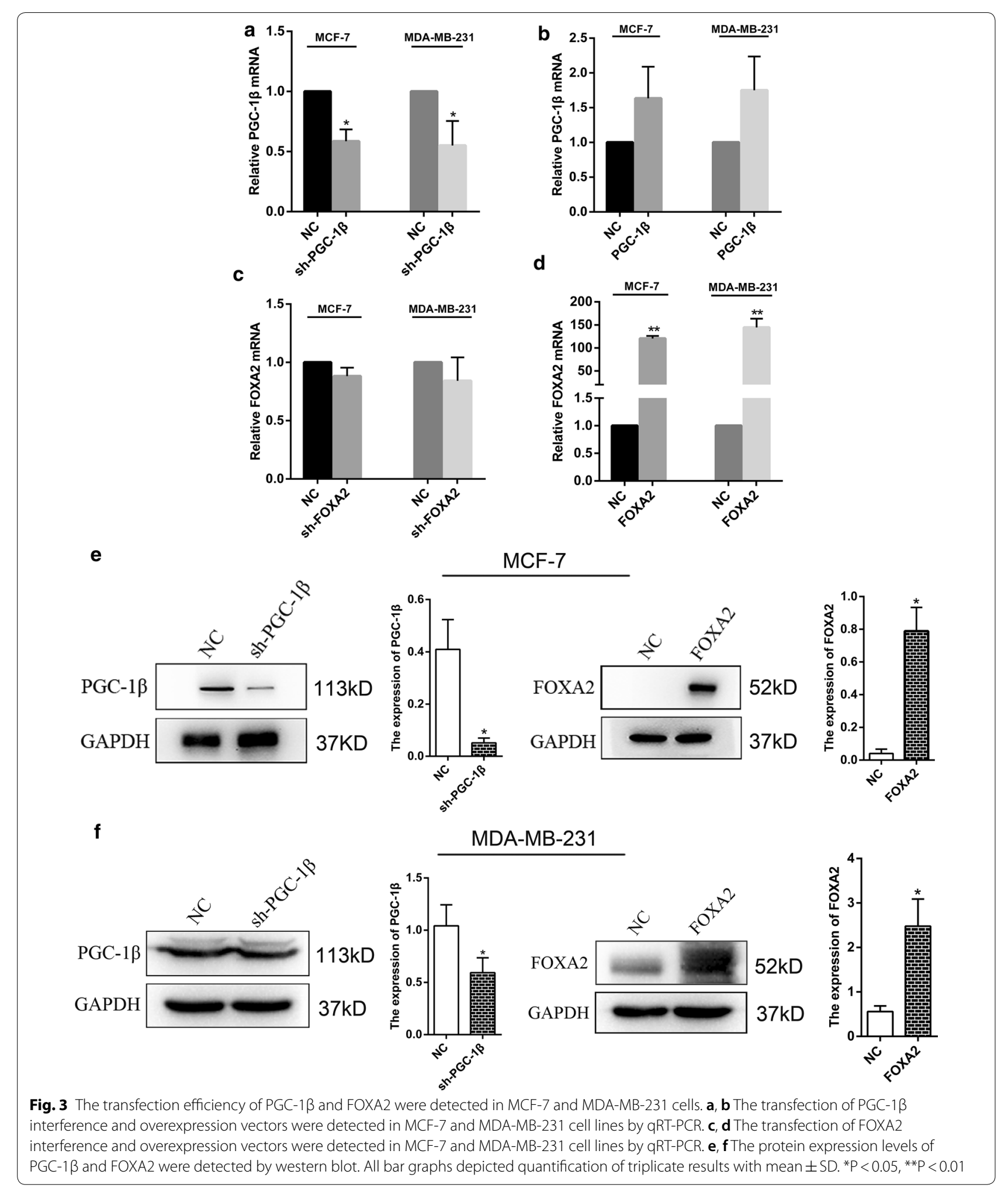




\section{Knockdown of PGC- $1 \beta$ combined with overexpression of FOXA2 inhibited proliferation and migration of breast cancer cells in vitro}

To explore the biological functions of $P G C-1 \beta$ and FOXA2 in breast cancer progression, we examined the effects of both genes on cell proliferation and clonogenicity by CCK- 8 and colony formation assays. The results demonstrated that the cell viability and proliferation were inhibited in MCF-7 and MDA-MB-231 cells after knockdown of PGC-1 $\beta$ or overexpression of FOXA2. It is worth noting that co-transfection with plasmids of sh-PGC-1 $\beta$ and FOXA2 dramatically reduced cell proliferation ability compared with individual transfection (Fig. 4a, b). Afterwards, we assessed whether PGC-1 $\beta$ and FOXA2 were involved in regulating the cells migration. Consistent with the above results, the cell migration was more significantly inhibited when co-transfected with both of plasmids (Fig. 4c, d). Overall, knockdown of PGC-1 $\beta$ combined with overexpression of FOXA2 apparently inhibited proliferation and migration of breast cancer cells in vitro.

\section{Suppression of PGC- $1 \beta$ in combination with overexpression of FOXA2 inhibited xenograft tumor growth and promoted apoptosis of breast cancer}

With AnnexinV-APC/PI staining and flow cytometry analysis, we evaluated the effects of PGC- $1 \beta$ and FOXA2 on cell apoptosis. The results indicated that downregulation of PGC- $1 \beta$ or upregulation of FOXA2 promoted apoptosis of MCF-7 and MDA-MB-231 cells compared to the control groups. Of note, co-transfection with plasmids of sh-PGC- $1 \beta$ and FOXA2 significantly increased cell apoptosis in comparison to that in cells with individual transfection (Fig. 5a, b). Subsequently, mouse subcutaneous xenograft experiments were performed to detect the effects of PGC-1 $\beta$ and FOXA2 on tumor growth in vivo. The tumor weight of xenografts derived from LV-sh-PGC-1 $\beta$ or LV-FOXA2 were significantly lighter compared with LV-NC. However, there was no significant difference in tumor weight when co-transplanted with LV-sh-PGC-1 $\beta$ and LV-FOXA2 $(\mathrm{P}>0.05$, Fig. 5c). Additionally, immunohistochemistry assay proved that PGC-1 $\beta$ inhibition or FOXA2 overexpression effectively reduced Ki67 expression compared with the NC group (Fig. 5d). The above results indicated that the combination of sh-PGC-1 $\beta$ and FOXA2 further suppressed xenograft tumor growth and promoted apoptosis in breast cancer.

\section{The combination of PGC-1 $\beta$ and FOXA2 inhibited breast tumor growth and metastasis through regulating the PI3K-AKT-mTOR signaling pathway}

PI3K-AKT-mTOR pathway has been reported that frequently involves in variety of human cancers and regulates numerous cellular processes, such as cell growth, proliferation and migration [34]. To investigate the molecular mechanisms of PGC-1 $\beta$ and FOXA2 in breast cancer progression, we detected the expression of related proteins of PI3K-AKT-mTOR pathway. The results showed that the expression of PGC-1 $\beta$, p-PI3K, p-AKT, PDK1, mTOR and Raptor were downregulated in MCF-7 cells when transfected with sh-PGC-1 $\beta$. However, the expression of FOXA2 was increased (Fig. 6a). Then, we found that the expression of p-PI3K, p-AKT, PDK1, p-mTOR, p-S6K1 and Raptor were significantly decreased when co-transfected with sh-PGC-1 $\beta$ and FOXA2 (Fig. 6b). To further prove the role of PI3K-AKTmTOR pathway in breast cancer growth and metastasis, we use rapamycin, an inhibitor of mTOR protein, to suppress the PI3K-AKT-mTOR pathway. We found the downregulation of p-PI3K, p-AKT and mTOR being induced (Fig. 6c). All the above results confirmed that the combination of PGC-1 $\beta$ and FOXA2 inhibited breast cancer cells proliferation, migration and induced apoptosis through regulating the PI3K-AKT-mTOR signaling pathway.

\section{Discussion}

It has been reported that the PGC-1 family exerts an important role in cancer metabolism and progression $[35,36]$. PGC- $1 \beta$ is a member of this family and acts as a central regulator in energy metabolism and other biological processes. And it exerts an important role in different cancers: Kumazoe et al. proved the FOXO3/PGC-1 $\beta$ signaling axis was essential for sustain the pancreatic ductal adenocarcinoma cancer stem cell properties [37]; Bellafante et al. reported the overexpression of PGC-1 $\beta$ has the ability to provide balance between enhanced mitochondrial activity and promoted intestinal carcinogenesis [38]. However, the direct correlation and specific

\footnotetext{
(See figure on next page.)

Fig. 4 Knockdown of PGC-1 $\beta$ combined with overexpression of FOXA2 inhibit proliferation and migration of breast cancer cells. MCF-7 and MDA-MB-231 cells were transfected with overexpression plasmid (FOXA2) and interference plasmid (sh-PGC-1 $\beta$ ) to detect the cell proliferation and migration. a Cell growth was evaluated by CCK-8 assay. $\mathbf{b}$ In vitro proliferative ability of two cell lines were detected by clone formation assay. c Cell metastatic was assessed using Transwell assay. (MCF-7: original magnification $\times 200$, scale bar $=50 \mu$ m; MDA-MB-231: original magnification $\times 40$, scale bar $=200 \mu \mathrm{m})$. $\mathbf{d}$ In vitro migration ability were detected using scratch wound healing assay $(\mathrm{scale} b a r=200 \mu \mathrm{m}) .{ }^{*} P<0.05,{ }^{* *} P<0.01$. ***P $<0.001$
} 
a

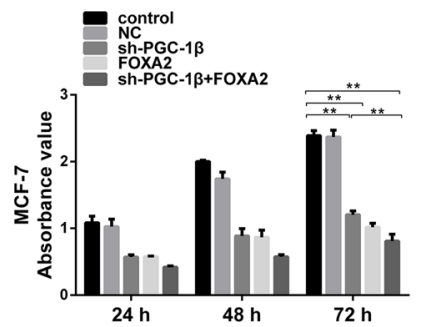

b

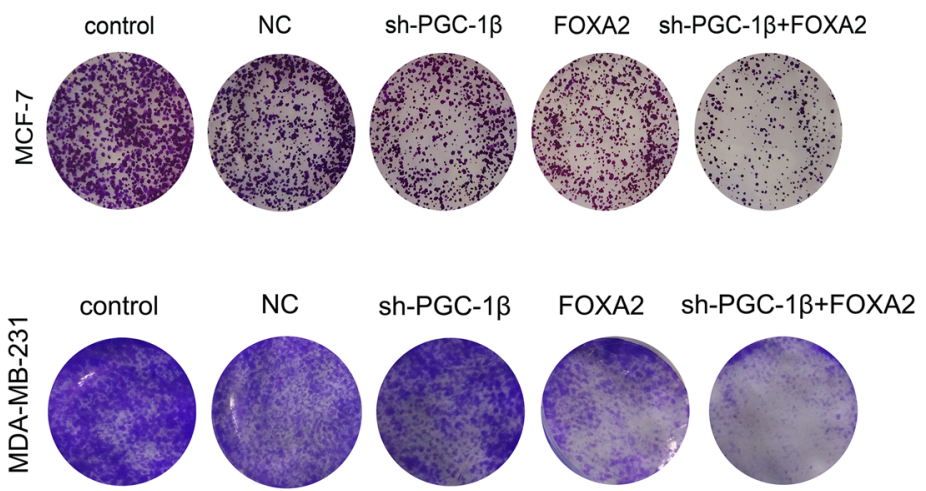

C
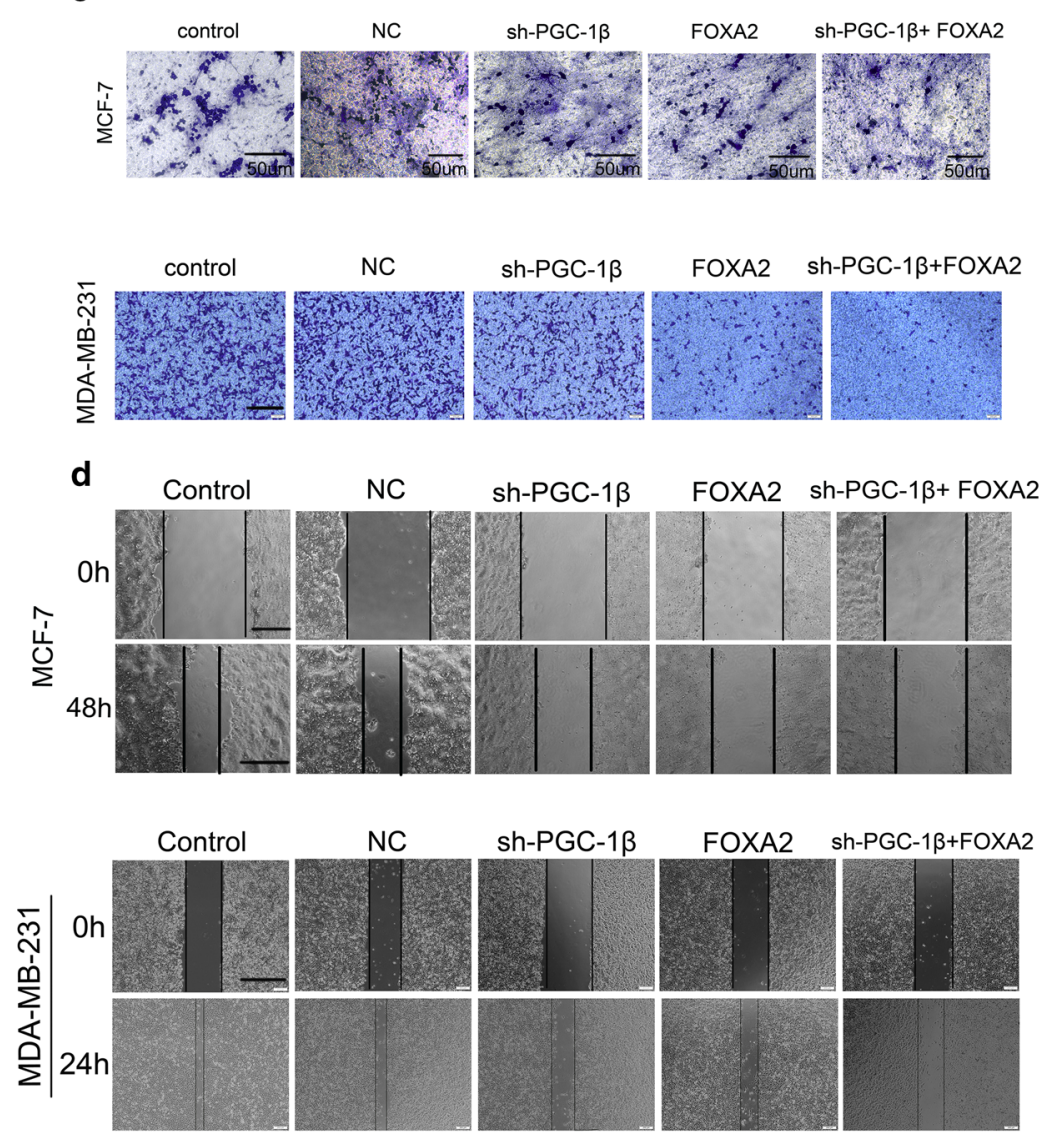
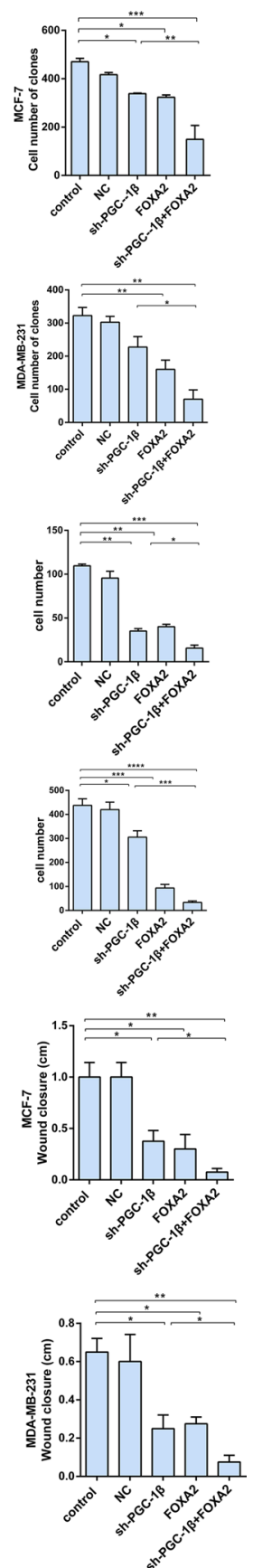

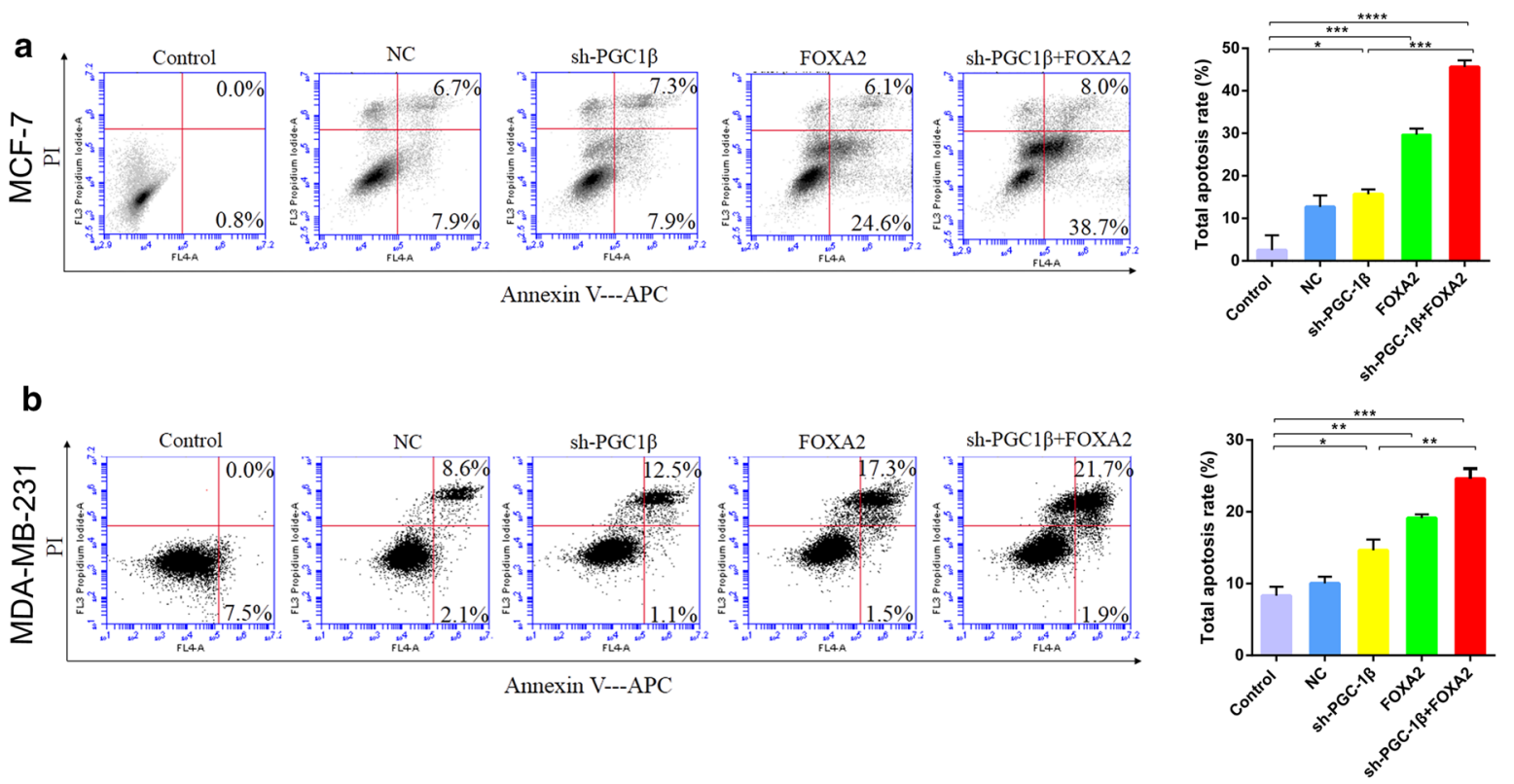

C
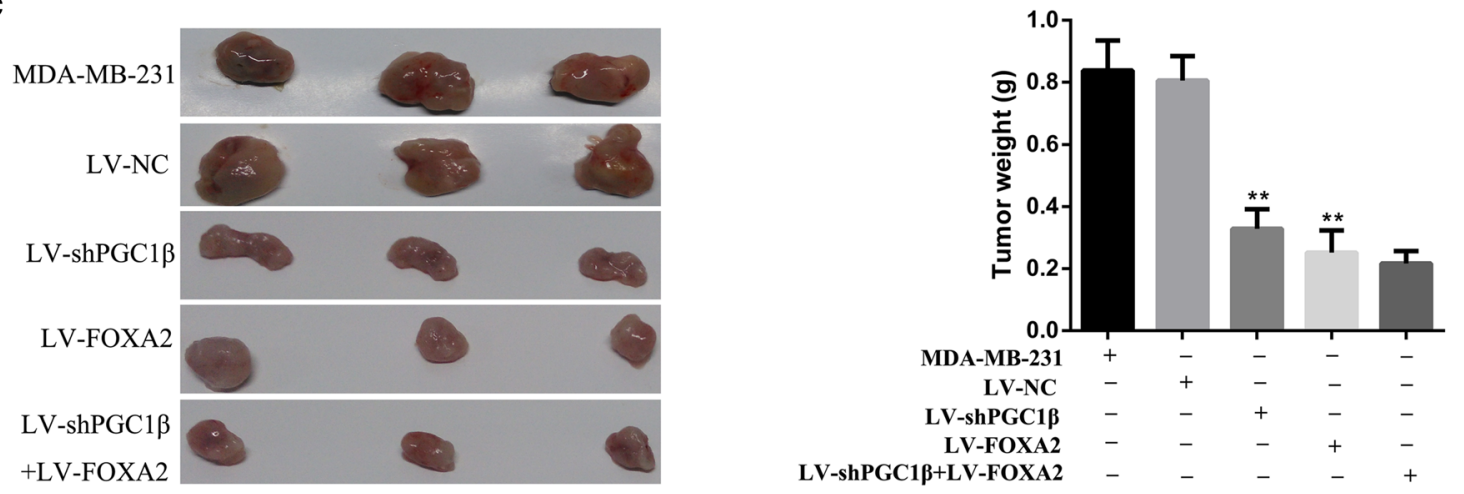

d

Ki67
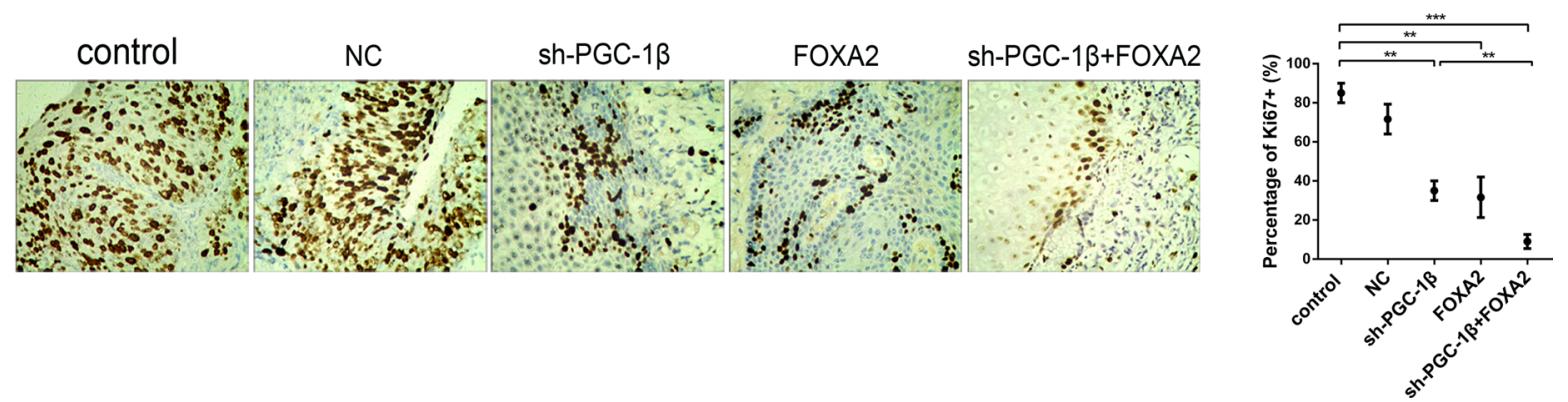

Fig. 5 Downregulation of PGC-1 $\beta$ combined with FOXA2 promote cell apoptosis and suppress xenograft tumor growth. $\mathbf{a}$, b Apoptosis assay was performed by flow cytometry using the Annexin V/PI staining. c Cells from each treatment group were injected subcutaneously into nude mice. The xenograft models were performed to detect the effect of PGC-1 $\beta$ and FOXA2 on breast cancer growth in vivo according to the tumor weight. $\mathbf{d}$ The expression of Ki67 were detected by immunohistochemical assay. ${ }^{*} \mathrm{P}<0.05,{ }^{* *} \mathrm{P}<0.01$, ${ }^{* * *} \mathrm{P}<0.001$

molecular mechanism between PGC-1 $\beta$ and breast cancer development remain unclear. Our previous research found that inhibition of endogenous PGC- $1 \beta$ induced cell apoptosis by regulating the mTOR pathway. In this study, we identified the PGC-1 $\beta$ was highly expressed in the progesterone receptor positive cell line MCF-7 and the high metastatic cell line MDA-MB-231. Meanwhile, PGC-1 $\beta$ was frequently overexpressed in breast 


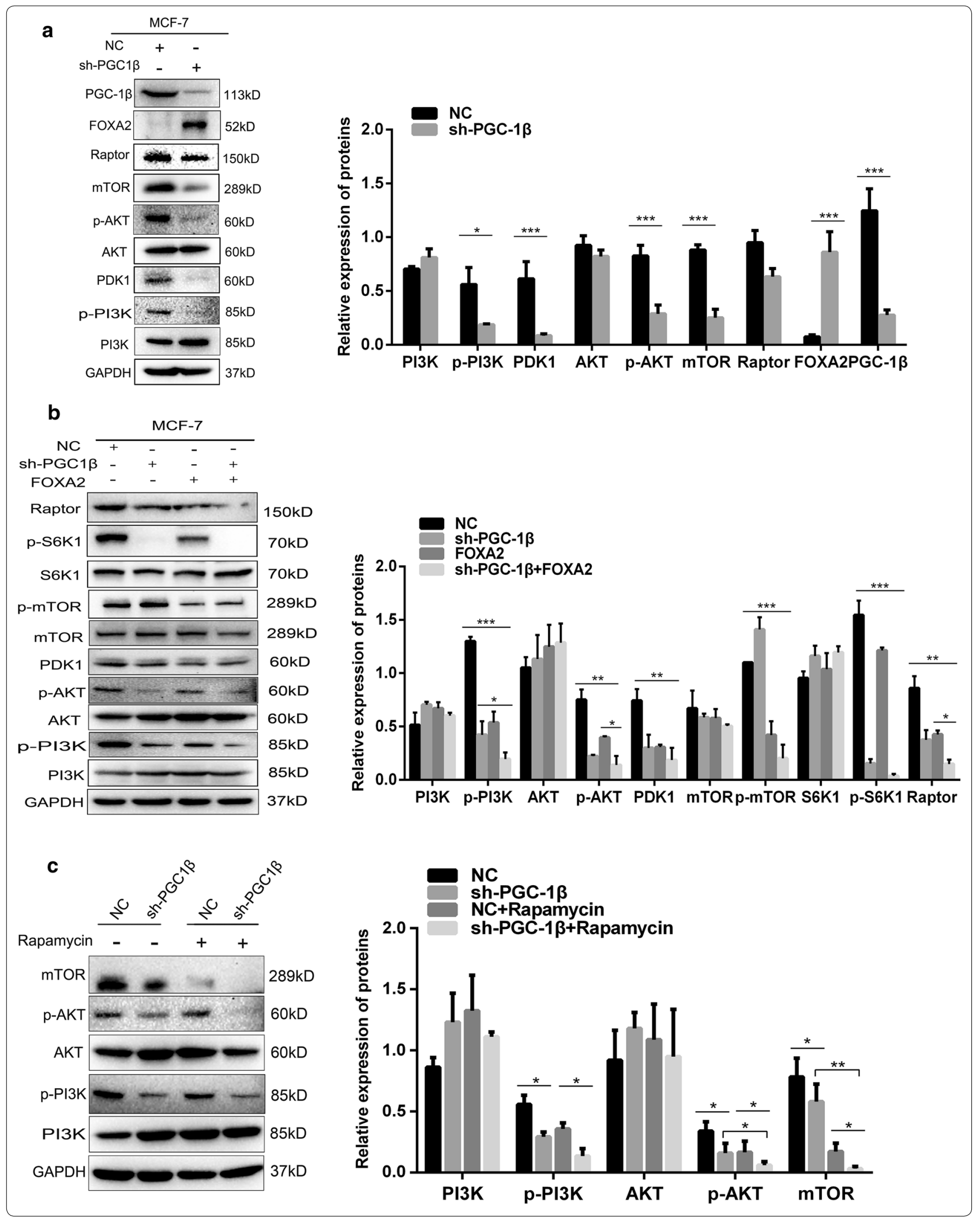


(See figure on previous page.)

Fig. 6 The combination of PGC-1 $\beta$ and FOXA2 inhibits breast tumor growth and metastasis through regulating the PI3K-AKT-mTOR signaling pathway. a The related proteins of PI3K-AKT-mTOR signal pathway were examined by western blot. GAPDH was used as loading control. b The related proteins of PI3K-AKT-mTOR signal pathway were evaluated in MCF-7 cells when co-transfected with sh-PGC-1 $\beta$ and FOXA2. c The protein levels of PI3K, p-PI3K, AKT, p-AKT, mTOR were detected after treatment of mTOR inhibitor rapamycin (1000 nM). Data are shown as mean \pm SD from three independent experiments. ${ }^{*} P<0.05$, ${ }^{* *} P<0.01$, ${ }^{* * *} P<0.001$

cancer tissues compared to adjacent non-cancerous tissues. According to the clinical data, PGC-1 $\beta$ expression is strongly correlation with breast cancer lymph node metastasis or progesterone receptor expression, which was consistent with the expression characteristics in the two cell lines. These results demonstrated that PGC- $1 \beta$ may be involved in the occurrence and metastasis of breast cancer.

FOXA2 is a member of forkhead/winged-helix family, which plays crucial role in organ genesis, cellular metabolism, and tumor development [39]. FOXA2 has the function of promoting cell proliferation and cancer stem cell maintenance in triple-negative breast cancer [28]. In lung adenocarcinoma, the developmental transcription factors FOXA2 and Cdx2 function cooperatively with Nkx2-1 as an important regulator in inhibiting metastasis [40]. Previous research has demonstrated that the coactivation of FOXA2 through PGC-1 $\beta$ promotes fatty acid oxidation and triglyceride/VLDL secretion in the liver [41]. Based on the above studies, we hypothesized the PGC- $1 \beta$ may cooperate with FOXA2 to regulate the occurrence and development of breast cancer. As expected, we found PGC-1 $\beta$ and FOXA2 colocalized in the nucleus, and PGC-1 $\beta$ interference combined with FOXA2 overexpression significantly inhibited the proliferation and migration of breast cancer cells. These results indicated that PGC-1 $\beta$ and FOXA2 can physically interact with each other, and FOXA2 is essential for PGC- $1 \beta$-induced biological function in breast cancer.

PI3K-AKT-mTOR is one of the major intracellular pathways, which serve a critical regulatory role among different kinds of tumor. mTOR is a key kinase of PI3K/ AKT downstream, it could regulate tumor cell proliferation, growth, survival and angiogenesis [42-44]. mTOR protein being proved to be regulated by two pathways. Including PI3K-AKT-mTOR pathway and PDK1-ERK/ MAPK-mTOR pathway [45]. Previous research proved that the PI3K-AKT-mTOR pathway involves the function of PGC-1 $\beta$ in regulating apoptosis of breast cancer cells. In this study, we detected the proteins expression of PI3K-AKT-mTOR signal pathway after transfected with PGC-1 $\beta$ and/or FOXA2 in breast cancer cells. The results showed PGC-1 $\beta$ cooperating with FOXA2 exerted their biological functions in breast cancer through regulating the PI3K-AKT-mTOR pathway. Although we have studied the impact of PGC- $1 \beta$ on breast cancer progression, there are still some deficiencies that need to be improved. More extensive research need to be explored to understand the mechanism of PGC-1 $\beta$ in breast cancer.

\section{Conclusions}

In conclusion, our study proved that PGC- $1 \beta$ was high expression while FOXA2 was low expression in breast cancer tissues and cell lines. Downregulation of PGC-1 $\beta$ combined with overexpression of FOXA2 obviously inhibited the breast cancer cells proliferation, migration and induced apoptosis through regulating the PI3KAKT-mTOR signaling pathway. Our findings reveal that PGC- $1 \beta$ may be serve as valuable diagnostic biomarker and potential therapeutic target for the development of breast cancer.

\section{Abbreviations}

PGC-1 $\beta$ : peroxisome gamma coactivator-1 $\beta$; FOXA2: forkhead box protein A2; qRT-PCR: real time quantitative reverse transcription-PCR; sh-PGC-1 $\beta$ : shRNA for PGC-1 $\beta$; NC: shRNA-NC; PGC-1 $\beta$ : pcDNA3.1-PGC-1 $\beta$; FOXA2: pcDNA3.1FOXA2; Co-IP: co-immunoprecipitation; IHC: immunohistochemistry; IF: immunofluorescence; ANOVA: analysis of variance.

\section{Authors' contributions}

$J C$ participated in the design of this study, collection of data, and drafting of the manuscript. XW and DNW analyzed statistically. RM, XHL, HMF and JW participated in data downloading and preliminary analysis. SHL and LBW revised the manuscript critically. All authors read and approved the final manuscript.

\section{Author details}

1 School of Clinical Medicine, Ningxia Medical University, Yinchuan 750004, China. ${ }^{2}$ Beijing National Biochip Research Center Sub-Center in Ningxia, The General Hospital of Ningxia Medical University, Yinchuan 750004, China. ${ }^{3}$ Medical Animal Lab, The Affiliated Hospital of Qingdao University, Qingdao 266003, China.

\section{Acknowledgements}

Not applicable.

\section{Competing interests}

The authors declare that they have no competing interests.

Availability of data and materials

Not applicable.

\section{Consent for publication \\ Not applicable.}

\section{Ethics approval and consent to participate}

All procedures performed in studies involving human participants and animals were in accordance with the ethical standards of The General Hospital of Ningxia Medical University. Informed consent was obtained from all patients in this study. 


\section{Funding}

This work was supported by grants from the National Natural Science Foundations of China Grant (No. 81860470, 81560474). The Science research project of Ningxia higher education (NGY2018-91). The First class discipline construction project in Colleges and Universities of Ningxia (Grant No.NXYLXK2017A05).

\section{Publisher's Note}

Springer Nature remains neutral with regard to jurisdictional claims in published maps and institutional affiliations.

Received: 10 December 2018 Accepted: 29 March 2019 Published online: 11 April 2019

\section{References}

1. Ferlay J, Soerjomataram I, Dikshit R, Eser S, Mathers C, Rebelo M, Parkin D, Forman D, Bray F. Cancer incidence and mortality worldwide: sources, methods and major patterns in GLOBOCAN 2012. Int J Cancer. 2015;136(5):E359-86.

2. Zeng Y, Sang J. Five zinc finger protein 350 single nucleotide polymorphisms and the risks of breast cancer: a meta-analysis. Oncotarget. 2017:8(63):107273-82.

3. Hamurcu Z, Delibaşı N, Geçene S, Şener E, Dönmez-Altuntaş H, Özkul Y, Canatan H, Ozpolat B. Targeting LC3 and Beclin-1 autophagy genes suppresses proliferation, survival, migration and invasion by inhibition of Cyclin-D1 and UPAR/Integrin $\beta 1 /$ Src signaling in triple negative breast cancer cells. J Cancer Res Clin Oncol. 2017;144(3):415-30.

4. Lin J, Handschin C, Spiegelman B. Metabolic control through the PGC-1 family of transcription coactivators. Cell Metab. 2005;1(6):361-70.

5. Ahmad S, Valli H, Salvage S, Grace A, Jeevaratnam K, Huang C. Agedependent electrocardiographic changes in Pgc-1 $\beta$ deficient murine hearts. Clin Exp Pharmacol Physiol. 2018;45(2):174-86.

6. Liu C, Lin J. PGC-1 coactivators in the control of energy metabolism. Acta Biochim Biophys Sin (Shanghai). 2011;43(4):248-57.

7. Schilling J, Kelly D. The PGC-1 cascade as a therapeutic target for heart failure. J Mol Cell Cardiol. 2011;51(4):578-83.

8. Riehle C, Wende A, Zaha V, Pires K, Wayment B, Olsen C, Bugger H, Buchanan J, Wang $X$, Moreira A, et al. PGC-1 $\beta$ deficiency accelerates the transition to heart failure in pressure overload hypertrophy. Circ Res. 2011;109(7):783-93.

9. Lehman J, Barger P, Kovacs A, Saffitz J, Medeiros D, Kelly D. Peroxisome proliferator-activated receptor gamma coactivator-1 promotes cardiac mitochondrial biogenesis. J Clin Invest. 2000;106(7):847-56.

10. Lin J, Wu H, Tarr P, Zhang C, Wu Z, Boss O, Michael L, Puigserver P, Isotani E, Olson E, et al. Transcriptional co-activator PGC-1 alpha drives the formation of slow-twitch muscle fibres. Nature. 2002;418(6899):797-801.

11. Lee S, Leone T, Rogosa L, Rumsey J, Ayala J, Coen P, Fitts R, Vega R, Kelly D. Skeletal muscle PGC-1 $\beta$ signaling is sufficient to drive an endurance exercise phenotype and to counteract components of detraining in mice. Am J Physiol Endocrinol Metab. 2017;312(5):E394-406.

12. Huss J, Torra I, Staels B, Giguère V, Kelly D. Estrogen-related receptor alpha directs peroxisome proliferator-activated receptor alpha signaling in the transcriptional control of energy metabolism in cardiac and skeletal muscle. Mol Cell Biol. 2004;24(20):9079-91.

13. Arany Z, He H, Lin J, Hoyer K, Handschin C, Toka O, Ahmad F, Matsui T, Chin S, Wu P, et al. Transcriptional coactivator PGC-1 alpha controls the energy state and contractile function of cardiac muscle. Cell Metab. 2005;1(4):259-71.

14. Andersen G, Wegner L, Yanagisawa K, Rose C, Lin J, Glümer C, Drivsholm T, Borch-Johnsen K, Jørgensen T, Hansen T, et al. Evidence of an association between genetic variation of the coactivator PGC-1 beta and obesity. J Med Genet. 2005;42(5):402-7.

15. Enguix N, Pardo R, González A, López V, Simó R, Kralli A, Villena J. Mice lacking $P G C-1 \beta$ in adipose tissues reveal a dissociation between mitochondrial dysfunction and insulin resistance. Mol Metab. 2013;2(3):215-26.

16. Piccinin E, Peres C, Bellafante E, Ducheix S, Pinto C, Villani G, Moschetta A. Hepatic PPARy coactivator $1 \beta$ drives mitochondrial and anabolic signatures that contribute to hepatocellular carcinoma progression. Hepatology (Baltimore, MD). 2018;67(3):884-98.

17. Victorino V, Barroso W, Assunção A, Cury V, Jeremias I, Petroni R, Chausse B, Ariga S, Herrera A, Panis C, et al. PGC-1 $\beta$ regulates HER2-overexpressing breast cancer cells proliferation by metabolic and redox pathways. Tumour Biol. 2016;37(5):6035-44.

18. Wang L, Liu Q, Li F, Qiu J, Fan H, Ma H, Zhu Y, Wu L, Han X, Yang Z, et al. Apoptosis induced by PGC-1 $\beta$ in breast cancer cells is mediated by the mTOR pathway. Oncol Rep. 2013;30(4):1631-8.

19. Mfopou J, Geeraerts M, Dejene R, Van Langenhoven S, Aberkane A, Van Grunsven L, Bouwens L. Efficient definitive endoderm induction from mouse embryonic stem cell adherent cultures: a rapid screening model for differentiation studies. Stem Cell Res. 2014;12(1):166-77.

20. Kaestner K, Knochel W, Martinez D. Unified nomenclature for the winged helix/forkhead transcription factors. Genes Dev. 2000;14(2):142-6.

21. Bonnavion R, Teinturier R, Gherardi S, Leteurtre E, Yu R, Cordier-Bussat M, Du R, Pattou F, Vantyghem M, Bertolino P, et al. Foxa2, a novel protein partner of the tumour suppressor menin, is deregulated in mouse and human MEN1 glucagonomas. J Pathol. 2017;242(1):90-101.

22. Ozaki T, Matsubara T, Seo D, Okamoto M, Nagashima K, Sasaki Y, Hayase S, Murata T, Liao X, Hanson J, et al. Thyroid regeneration: characterization of clear cells after partial thyroidectomy. Endocrinology. 2012;153(5):2514-25

23. Chu G, Zhau H, Wang R, Rogatko A, Feng X, Zayzafoon M, Liu Y, FarachCarson M, You S, Kim J, et al. RANK- and c-Met-mediated signal network promotes prostate cancer metastatic colonization. Endocr Relat Cancer. 2014;21(2):311-26.

24. Cao L, Gibson J, Miyamoto S, Sail V, Verma R, Rosenberg D, Nelson C, Giardina C. Intestinal lineage commitment of embryonic stem cells. Differentiation. 2011;81(1):1-10.

25. Kaestner $\mathrm{K}$. The making of the liver: developmental competence in foregut endoderm and induction of the hepatogenic program. Cell Cycle. 2005;4(9):1146-8.

26. Gao N, LeLay J, Vatamaniuk M, Rieck S, Friedman J, Kaestner K. Dynamic regulation of $\mathrm{Pdx} 1$ enhancers by Foxa1 and Foxa2 is essential for pancreas development. Genes Dev. 2008;22(24):3435-48.

27. Zhang Z, Yang C, Gao W, Chen T, Qian T, Hu J, Tan Y. FOXA2 attenuates the epithelial to mesenchymal transition by regulating the transcription of E-cadherin and ZEB2 in human breast cancer. Cancer Lett. 2015;361(2):240-50

28. Perez-Balaguer A, Ortiz-Martínez F, García-Martínez A, Pomares-Navarro C, Lerma E, Peiró G. FOXA2 mRNA expression is associated with relapse in patients with Triple-Negative/Basal-like breast carcinoma. Breast Cancer Res Treat. 2015;153(2):465-74.

29. Myatt S, Lam E. The emerging roles of forkhead box (Fox) proteins in cancer. Nat Rev Cancer. 2007;7(11):847-59.

30. Friedman J, Kaestner K. The Foxa family of transcription factors in development and metabolism. Cell Mol Life Sci. 2006;63(19-20):2317-28.

31. Kaestner K. The FoxA factors in organogenesis and differentiation. Curr Opin Genet Dev. 2010;20(5):527-32.

32. Song $Y$, Washington $M$, Crawford $H$. Loss of FOXA1/2 is essential for the epithelial-to-mesenchymal transition in pancreatic cancer. Cancer Res. 2010;70(5):2115-25.

33. Tu M, Pan Y, Qiu J, Kim E, Yu A. MicroRNA-1291 targets the FOXA2-AGR2 pathway to suppress pancreatic cancer cell proliferation and tumorigenesis. Oncotarget. 2016;7(29):45547-61.

34. Fruman D, Rommel C. PI3K and cancer: lessons, challenges and opportunities. Nat Rev Drug Discov. 2014;13(2):140-56.

35. Deblois G, St-Pierre J, Giguère V. The PGC-1/ERR signaling axis in cancer. Oncogene. 2013;32(30):3483-90.

36. Girnun $\mathrm{G}$. The diverse role of the PPARy coactivator 1 family of transcriptional coactivators in cancer. Semin Cell Dev Biol. 2012;23(4):381-8.

37. Kumazoe M, Takai M, Hiroi S, Takeuchi C, Kadomatsu M, Nojiri T, Onda H, Bae J, Huang Y, Takamatsu K, et al. The FOXO3/PGC-1 beta signaling axis is essential for cancer stem cell properties of pancreatic ductal adenocarcinoma. J Biol Chem. 2017;292(26):10813-23.

38. Bellafante E, Morgano A, Salvatore L, Murzilli S, Di Tullio G, D'Orazio A, Latorre D, Villani G, Moschetta A. PGC-1ß promotes enterocyte lifespan and tumorigenesis in the intestine. In: Proceedings of the National Academy of Sciences of the United States of America. 2014;111(42):E4523-31. 
39. Sekiya T, Muthurajan U, Luger K, Tulin A, Zaret K. Nucleosome-binding affinity as a primary determinant of the nuclear mobility of the pioneer transcription factor FoxA. Genes Dev. 2009;23(7):804-9.

40. Li C, Gocheva V, Oudin M, Bhutkar A, Wang S, Date S, Ng S, Whittaker C, Bronson R, Snyder E, et al. Foxa2 and Cdx2 cooperate with Nkx2-1 to inhibit lung adenocarcinoma metastasis. Genes Dev. 2015;29(17):1850-62

41. Wolfrum C, Stoffel M. Coactivation of Foxa2 through Pgc-1 beta promotes liver fatty acid oxidation and triglyceride/NLDL secretion. Cell Metab. 2006;3(2):99-110.

42. Saxton R, Sabatini D. mTOR signaling in growth, metabolism, and disease. Cell. 2017;168(6):960-76.
43. Lau M, Leung P. The PI3K/Akt/mTOR signaling pathway mediates insulinlike growth factor 1 -induced E-cadherin down-regulation and cell proliferation in ovarian cancer cells. Cancer Lett. 2012;326(2):191-8.

44. Liu X, Jiang Q, Liu H, Luo S. Vitexin induces apoptosis through mitochondrial pathway and PI3K/Akt/mTOR signaling in human non-small cell lung cancer A549 cells. Biol Res. 2019;52(1):7.

45. Woodcock HV, Eley JD, Guillotin D, Platé M, Nanthakumar CB, Martufi M, Peace S, Joberty G, Poeckel D, Good RB, et al. The mTORC1/4E-BP1 axis represents a critical signaling node during fibrogenesis. Nat Commun. 2019;10(1):6.
Ready to submit your research? Choose BMC and benefit from:

- fast, convenient online submission

- thorough peer review by experienced researchers in your field

- rapid publication on acceptance

- support for research data, including large and complex data types

- gold Open Access which fosters wider collaboration and increased citations

- maximum visibility for your research: over $100 \mathrm{M}$ website views per year

At BMC, research is always in progress.

Learn more biomedcentral.com/submissions 